\title{
Retention-Oriented Curricular Design
}

Ivana Milanovic, University of Hartford, USA

Tom A. Eppes, University of Hartford, USA

Janice Girouard, University of Hartford, USA

Lee Townsend, University of Hartford, USA

\begin{abstract}
This paper presents a retention-oriented approach to the educational value stream within the STEM undergraduate area. Faced with several strategic challenges and opportunities, a Flex Advantage Plan was developed to enhance the undergraduate engineering technology programs and better utilize the curricular flexibilities inherent in the current structure. FAP provides distinction and uniqueness to these majors by presenting students with educational choices that add depth in a chosen discipline and/or another concentration. Flex Advantage has expanded awareness and increased enrollment in secondary degrees, minors and concentrations. In the next phase, the linkages between undergraduate and graduate studies will be addressed to provide a smoother transition for current undergraduate students and more relevant alternatives for parttime students.
\end{abstract}

Keywords: engineering technology, flexibility, curriculum, minor, concentration

\section{INTRODUCTION}

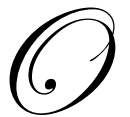

ur University is primarily an in-residence undergraduate institution. The College offers degrees in the disciplines of Engineering (E), Engineering Technology (ET), and Architecture with a population of about 900 students enrolled approximately as follows: 400 in ET, 400 in E and 100 pursuing a Masters of Engineering. In the past ten years, undergraduate enrollment experienced consistent year-to-year increases. The campus is conveniently located among a vibrant array of high technology companies which over time has offered excellent employment opportunities for E/ET graduates.

Two key strategic objectives of the College are managed growth and improved retention. Our experience is that these can best be accomplished by fostering unique and distinctive programs. The College has three departments that collectively support undergraduate ET programs:

- $\quad$ Architectural Engineering Technology (AET) in the Architecture Department

- $\quad$ Audio (AuET), Electronic (EET) and Computer Engineering Technology (CET) in the Electrical \& Computer Engineering Department

- $\quad$ Mechanical Engineering Technology (MET) in Mechanical Engineering Department

Some departments feature both E and ET majors, hence differentiation is important for both external recruiting and internal transfers. In addition, enrollment volume and student interests within ET vary widely. Two of the largest programs, AET and AuET, are quite unique with more opportunities for students to express creativity early in their studies. In contrast, CET, EET, and MET, are offered by many other institutions and generally perceived as more technically focused and challenging (Girouard, J., 2006). Within larger majors, study groups and informal support groups are easily formed and sustained. In small majors students do not engage in such activities and, predictably, retention has been lower. Small ET programs also experience lower average SAT scores with greater dispersion from top to bottom. Well-qualified ET students sometimes opt to either transfer to engineering within the College or leave the University. For the above reasons, there is an ongoing need to better leverage the inherent curricular flexibilities resident within ET. 
The College's recruiting environment is complicated by a number of emerging factors. First, many students seek to broaden their skill base upon graduation and must increasingly compete in a global marketplace. Secondly, an in-state public high school drop in graduates of 9.4\% is forecasted from 2008-16 (State of Connecticut, 2007). This downward trend is mirrored nationally with similar predicted declines with no reversal until 2016 (The College Board, 2005). Thirdly, a higher percentage of high school graduates will come from families with low incomes (WICHE, 2003). Moreover, parents and students are experiencing economic challenges that require greater financial aid packages reducing the net income to the University for the same enrollment. The University is a private institution highly dependent on tuition revenue so it is imperative that these challenges be met especially at the undergraduate level.

This paper describes our response to the strategic challenges by: (1) strengthening ET distinctiveness and (2) creating more flexible curricula. Since FAP was introduced, more ET students have decided to pursue multiple avenues of study which has benefited retention since rich educational offerings integrated across programs may not be available from other institutions in the region.

\section{FLEX ADVANTAGE PLAN}

Flex Advantage Plan (FAP) was developed for undergraduate ET programs to leverage their inherent curricular flexibilities by better use of electives. Until recently, the systematic use of electives in the academic advising process was done by self-motivated faculty and students. To create a more consistent and sustainable approach, specific options that produce educational value with minimal credit overload were identified and offered in FAP.

Students are presented with educational choices that add depth in a discipline and/or another concentration. Curricula designed along these lines deliver a richer experience, expand skills and present graduates with a broader array of options.

Several universities have reported initiatives to augment and promote more flexible educational pathways. Michigan Technological University announced an accredited engineering degree that allows students flexibility in pursuing interests outside of engineering (Sorby, S.A., 2003). Northeastern University launched a focus on energy, bio-engineering, bio-technology, building engineering services, industrial and robotic control, security, entrepreneurial product development and transportation, all available as an minor regardless of major (Tapper, J., 2008). The College of Engineering at the University of Iowa adopted a curriculum that features more course electives (Nixon, W., and Stoner, J., 2008). Recently, a two-pronged curricular approach was proposed as a way to sustain and enhance manufacturing engineering with a minor in bio- or biomedical engineering as well as a double major opportunity (Sirinterlikici, A., 2010). These efforts have been exclusively focused on E programs. In contrast, FAP is the first reported holistic approach that targets ET programs.

FAP curricular options featuring three tracks, Business Advantage, Arts \& Communication and Technical Depth are illustrated in Table 1. The Business Advantage offers up to six minors. Arts \& Communication is popular with Architecture and Audio majors since it resonates with the artistic interests often observed in these students. Technical Depth affords the largest number of choices with a multi-disciplinary array of associate's of science (AS) degrees, minors and concentrations. Since its introduction, FAP has and continues to evolve as new options are introduced and made available.

Within a given major, some pathways have traditionally been more popular than others. This is driven largely by those course bundles that best fulfill a student's goals and desires. Business Advantage yields three to five minors and is driven by the number of available vs. required courses that can be exploited within the curriculum. In Arts \& Communication, there are five possible minors. Students majoring in AuET may choose between Communication and Cinema/Film while AET students may select between Fine Arts and Art History. To expand Technical Depth, students may pursue an AS degree, minor or simply a concentration. Presently, AuET majors have the most flexibility: Business Advantage (4), Arts \& Communication (2) or Technical Depth (7). A popular choice among AuET students has been the AS degree in EET since it only requires two additional courses. Interest is rising among MET students for the AS EET degree since their curriculum already contains five electronic courses. 
The use of electives to achieve incremental educational goals had been underutilized even though a wide selection of minors and AS degrees was available. FAP was created to improve enrollment and retention by encouraging early adoption and integrating the course plan into the advising process. FAP uses two curricular components: Professional Electives (PEs) and Technical Specialties (TSs). Professional Electives are traditionally chosen from ET, engineering, science, mathematics, business, computer science, music, communication, arts or education offerings. During the advising process, students are counseled to select PEs that contribute to a stated career goal(s) and/or objective(s). While electives may nourish intellectual curiosity or artistic expression beyond one's declared major, they also enable the pursuit of associates degrees, minors and concentrations.

Since the goal of most students is to graduate as soon as possible, electives had been typically chosen out of expediency and therefore underutilized. By implementing a more flexible curricular structure supported early-on by the advising process, simultaneous achievement of grade point average (GPA), in-time graduation, and accomplishment of broader educational objectives can be achieved.

Table 1: FAP Curricular Options by ET Program

\begin{tabular}{|c|c|c|c|}
\hline Program & $\begin{array}{l}\text { Business Advantage } \\
\text { (minors) }\end{array}$ & $\begin{array}{l}\text { Arts \& Communication } \\
\text { (minors) }\end{array}$ & $\begin{array}{l}\text { Technical Depth (degrees \& } \\
\text { minors) }\end{array}$ \\
\hline AET & $\begin{array}{ll}\text { - } & \text { Business Admin. } \\
\text { - } & \text { Management } \\
\text { - } & \text { Marketing }\end{array}$ & $\begin{array}{ll}\text { - } & \text { Art History } \\
\text { - } & \text { Fine Arts } \\
\text { - } & \text { Spanish }\end{array}$ & $\begin{array}{ll}\text { - } & \text { MET minor } \\
\text { - } & \text { Civil Engr. Minor } \\
\text { - } & \text { Comp. Sci. minor }\end{array}$ \\
\hline AuET & $\begin{array}{ll}\text { - } & \text { Business Admin. } \\
\text { - } & \text { Entrepreneurship } \\
\text { - } & \text { Management } \\
& \text { Marketing }\end{array}$ & $\begin{array}{ll}\text { - } & \text { Cinema/Film } \\
\text { - } & \text { Communication }\end{array}$ & $\begin{array}{ll}\text { - } & \text { AS CET } \\
\text { - } & \text { AS EET } \\
\text { - } & \text { CET minor } \\
\text { - } & \text { EET minor } \\
\text { - } & \text { MET minor } \\
\text { - } & \text { Math minor } \\
\text { - } & \text { Comp. Sci. minor }\end{array}$ \\
\hline CET & $\begin{array}{ll}\text { - } & \text { Business Admin. } \\
\text { - } & \text { Entrepreneurship } \\
\text { - } & \text { Management } \\
\text { - } & \text { Management Info. Systems } \\
\text { - } & \text { Marketing }\end{array}$ & & $\begin{array}{ll}\text { - } & \text { AS EET } \\
\text { - } & \text { Comp. Networking } \\
\text { - } & \text { Comp. Sci. minor }\end{array}$ \\
\hline EET & $\begin{array}{ll} & \text { Business Admin } \\
\text { - } & \text { Entrepreneurship } \\
\text { - } & \text { Management } \\
\text { - } & \text { Management Info. Systems } \\
\text { - } & \text { Marketing }\end{array}$ & & $\begin{array}{ll}\text { - } & \text { AS CET } \\
\text { - } & \text { AuET minor } \\
\text { - } & \text { CET minor } \\
\text { - } & \text { MET minor } \\
- & \text { Math minor } \\
\circ & \text { Mechatronics }\end{array}$ \\
\hline MET & $\begin{array}{ll}\text { - } & \text { Business Admin. } \\
\text { - } & \text { Entrepreneurship } \\
\text { - } & \text { Management } \\
\text { - } & \text { Marketing }\end{array}$ & - $\quad$ Fine Arts & $\begin{array}{ll}\text { - } & \text { AS EET } \\
\text { - } & \text { AuET minor } \\
\text { - } & \text { CET minor } \\
\text { - } & \text { EET minor } \\
\text { - } & \text { Math minor } \\
\circ & \text { Mechatronics }\end{array}$ \\
\hline \multicolumn{4}{|c|}{$\begin{array}{ll}\text { - } & \text { Currently in place } \\
\circ & \text { Future offering }\end{array}$} \\
\hline
\end{tabular}

\section{IMPLEMENTATION}

FAP was implemented so that every opportunity and resource within the College would encourage students to expand their undergraduate educational objectives. This helped overcome the tendency to discover an interest in 
additional educational options late in the course of study. Internal advising processes were revamped and a calendar of key events was created to stimulate awareness, communicate benefits and drive participation. Staff and faculty adoption has been the most critical factor in FAP's success. The implementation plan consisted of three levels of constituent engagement: awareness, engagement and reinforcement.

\section{Awareness}

- $\quad$ Industry Partners - The support and buy-in from industry partners is essential to the long term success of our graduates. This is best accomplished by collaborating with contacts at both the technical and managerial levels across a full range of student-focused venues.

- $\quad$ Marketing Collateral - The College publishes and distributes brochures throughout the academic year. Most are mailed to prospective students or handed out at open house events. In addition, the College and Departments publish web content that explains FAP options in detail.

- $\quad$ Open House Events - A number of undergraduate open houses are held each academic year. These events are ideal opportunities to discuss specific merits and the various options within each course of study.

- Institutional Awareness- Grant officers working with donors had not been aware of the E/ET distinction resulting in most support being given for E scholarships.

\section{Engagement}

- $\quad$ 1st Year Orientation - FAP is covered extensively in the first-year orientation course for all ET majors. Students are encouraged to set educational goals early to maximize the flexibilities and develop a detailed plan to accomplish them.

\section{Reinforcement}

- Undergraduate Academic Advising - Advising is used as an opportunity to present and discuss educational plans and follow up on progress within the major as well as with other pathways that have been elected.

\section{RESULTS}

The enrollment history of ET majors is shown in Table 2 for the last six years. Academic years 2004-05 and 2005-06 represent the baseline of participation. Since FAP's introduction in AY 2006-07, the number of students graduating with minors, associate degrees and concentrations has risen significantly. Within the AET major, approximately $7 \%$ of the students now consistently pursue a minor. The most dramatic change has been in AuET where many opt for minors and/or an AS degree. Audio is a small and highly specialized field so students need to demonstrate breath in electronics to qualify for other job opportunities. CET and EET have small enrollments, but a healthy fraction typically pursue an AS degree. For the MET major, a significant number choose one or both of two options, a minor in Business or a minor in EET.

FAP is featured prominently in open house presentations each fall semester. For most parents and students, this is the first opportunity to learn more about programs of interest and interact directly with faculty and staff. Most visitors in these events are surprised by the large number of associate degrees and minors that are possible within a four-year course of study. During the last six academic years, first-year enrollment in ET programs has increased by an average of $6 \%$. While many actions have been taken that contribute to this improvement, FAP has certainly been an important factor. In the future, additional data will be collected to measure the impact on retention for secondyear students and first-year students who participate in FAP. 
Table 2: FAP Options of ET Graduates by Program

\begin{tabular}{|c|c|c|c|c|c|c|c|}
\hline Major & Option & AY 04-05 & AY 05-06 & AY 06-07 & AY 07-08 & AY 08-09 & AY 09-10 \\
\hline \multirow{8}{*}{ AET } & Bus. Mgt. & & & & 1 & & \\
\hline & Art History & & & & & 1 & 1 \\
\hline & Fine Arts & & & 1 & 1 & & \\
\hline & Spanish & & & 1 & 1 & & \\
\hline & Civil Engr. & & & & & 2 & \\
\hline & Comp. Sci. & & & & & 1 & \\
\hline & Total FAP & $\mathbf{0}$ & $\mathbf{0}$ & 2 & 3 & 4 & 1 \\
\hline & Total Graduates & 28 & 16 & 34 & 36 & 37 & 27 \\
\hline \multirow{9}{*}{ AuET } & Bus. Admin. & & 1 & 1 & 1 & & 1 \\
\hline & Bus. Mktg. & & & 1 & & & \\
\hline & Cinema & & & & 5 & & \\
\hline & Comm. & & & & 4 & & \\
\hline & Comp. Sci. & & & 2 & & & \\
\hline & Math & & & & 2 & & \\
\hline & AS in EET & & 4 & & 20 & 4 & 5 \\
\hline & Total FAP & $\mathbf{0}$ & 5 & 4 & 32 & 4 & 6 \\
\hline & Total Graduates & 9 & 22 & 16 & 27 & 10 & 18 \\
\hline \multirow{4}{*}{ CET } & Bus. Admin. & 1 & & & & & \\
\hline & Comp. Sci. & 1 & & & & & \\
\hline & Total FAP & 2 & $\mathbf{0}$ & $\mathbf{0}$ & $\mathbf{0}$ & $\mathbf{0}$ & $\mathbf{0}$ \\
\hline & Total Graduates & 9 & 4 & $\mathbf{0}$ & 2 & 1 & 1 \\
\hline \multirow{5}{*}{ EET } & AuET & & & & 1 & & \\
\hline & Math & & & 1 & & & \\
\hline & AS in CET & 1 & & & & 2 & 1 \\
\hline & Total FAP & 1 & $\mathbf{0}$ & 1 & 1 & 2 & 1 \\
\hline & Total Graduates & 5 & 7 & 12 & 5 & 6 & 2 \\
\hline \multirow{7}{*}{ MET } & Bus. Admin. & & & & 7 & 2 & 1 \\
\hline & Bus. Mgt. & & & & & 2 & \\
\hline & AuET & & & & 1 & & \\
\hline & EET & & & & & 4 & 1 \\
\hline & Math & & & 1 & & 1 & \\
\hline & Total FAP & $\mathbf{0}$ & $\mathbf{0}$ & 1 & 8 & 9 & 2 \\
\hline & Total Graduates & 3 & 9 & 9 & 13 & 13 & 10 \\
\hline
\end{tabular}

\section{CONCLUSION}

Prompted by the strategic challenges and opportunities, FAP was developed and implemented for all ET programs. FAP has successfully taken advantage of inherent yet largely dormant curricular flexibilities. It has improved distinction and uniqueness by presenting students with opportunities to add depth in a chosen discipline and/or another area of study. Over the last four academic years, the number of student pursuing an educational objective beyond a single degree has increased considerably, and the goal of blanketing all students has been attained in some programs. FAP's strong value proposition and its consistent implementation within the College has certainly made a positive difference in ET enrollment and retention. 
Future plans include improving the linkages between the undergraduate and graduate studies. The goal is to create a smoother transition for current undergraduate students and relevant alternatives for part-time students. This more integrated approach is expected to drive enrollment increments once all of the proposed changes are implemented and communicated to the target market.

\section{AUTHOR INFORMATION}

Ivana Milanovic is an Associate Professor of Mechanical Engineering in the College of Engineering, Technology, and Architecture at the University of Hartford. She received her Ph.D. in Mechanical Engineering from Polytechnic University, NY, and M.S. and B.S. from University of Belgrade in Yugoslavia.

Tom Eppes is an Associate Professor of Electrical and Computer Engineering in the College of Engineering, Technology, and Architecture at the University of Hartford. He holds Bachelor and Master of Science degrees in Electrical Engineering from Texas A\&M University and a Ph.D. in Electrical Engineering from the University of Michigan.

Janice Girouard is the Manager of Student Services in the College of Engineering, Technology, and Architecture at the University of Hartford. She holds Bachelor of Fine Arts and Master of Education degrees from the University of Hartford.

Lee Townsend is an Assistant Professor of Physics and Mathematics in the College of Engineering, Technology, and Architecture at the University of Hartford. She holds an AB degree from Smith College and Master of Science and $\mathrm{PhD}$ degrees from the University of New Hampshire.

\section{REFERENCES}

1. Girouard, J., Milanovic, I. M., Segal, N., and Townsend, L. (2006). Retention Strategies in Smaller Technology Majors, ASEE Annual Conference Proceedings, Chicago, IL, Paper 2006-581.

2. State of Connecticut (2007). The Board of Governors for Higher Education, Report, Department of Higher Education.

3. The College Board (2005). The Impact of Demographic Changes on Higher Education, Philadelphia, PA, USA.

4. WICHE (2003). Western Interstate Commission for Higher Education, Knocking at the College Door: Projections of High School Graduates by State, Income, and Race/Ethnicity.

5. Sorby, S. A. (2003). An Accredited Engineering Degree Program with Flexibility Designed for StudentCentered Learning, ASEE Annual Conference Proceedings, Nashville, TN, Paper 2003-440.

6. Tapper, J. and Dibella, F. (2008). The Development and Deployment of an Engineering Technology Curriculum to Combat Engineering Globalization, ASEE Annual Conference Proceedings, Pittsburgh, PA, Paper 2008-1140.

7. Nixon, W. and Stoner, J. (2009). Impacts of Student Course Selection on Subsequent Career Trajectories, ASEE Annual Conference Proceedings, Austin, TX, Paper 2009-2007.

8. Sirinterlikici, A. and Mativo, J. (2010). Marrying Manufacturing Programs with Biological and Biomedical Engineering Fields, ASEE Annual Conference Proceedings, Louisville, KY, Paper 2010-2343. 